\title{
The effects of croscarmellose sodium concentration on the physicochemical characteristics of orodispersible tablets of atenolol
}

\author{
Nani Parfati, Karina Citra Rani* \\ Departement of Pharmacetics, Faculty of Pharmacy, \\ University of Surabaya, Surabaya \\ Jl. Kalirungkut Surabaya, Surabaya-60293, Jawa Timur, Indonesia
}

Submitted: 18-10-2017

Reviewed: 20-03-2018

Accepted: 29-04-2018

\begin{abstract}
Hypertension is the most common cardiovascular diseases suffered by geriatric patients. Their physiological changes make the administration of conventional tablets less effective, especially regarding compliance. One approach to overcome this problem is the development of orodispersible tablets, which soften easily and disintegrate quickly in the oral cavity. Atenolol is a class of $\beta$-blocker functioning as an anti-hypertensive drug that has been extensively used in hypertension therapy, and it has the potential to being developed as orodispersible tablets. A faster disintegration of orodispersible tablets will facilitate an earlier onset of dissolution. The addition of superdisintegrants can reduce the disintegration time of these tablets. Croscarmellose sodium is a superdisintegrant that can decrease the disintegration time to less than three minutes. This study aimed to optimize the formula of orodispersible tablets of atenolol using different concentrations of croscarmellose sodium, namely $10 \%$ (formula 1) and 20\% (formula 2). The physicochemical characteristics of the tablets were evaluated to determine the best formula. The evaluation included a comparison to the control formula ( $0 \%$ of croscarmellose sodium). The results showed that formula 1 (10\% of croscarmellose sodium) produced orodispersible tablets with the best physicochemical characteristics regarding tablet hardness, friability, in vitro dispersion time, and disintegration time. Formula $1\left(\% \mathrm{Q}_{30 \text { minutes }}=98.31 \%\right)$ also met the standard of the dissolution of atenolol tablets set by the Farmakope Indonesia, i.e., the percent of dissolved drug in 30 minutes has to be higher than $85 \%$. The drug dissolution efficiency of formula 1 was twice higher than that of the control formula.
\end{abstract}

Keywords: atenolol, croscarmellose sodium, hypertension, orodispersible tablets

\author{
Corresponding author: \\ Karina Citra Rani \\ Departement of Pharmacetics, Faculty of Pharmacy \\ University of Surabaya, Surabaya \\ Jl. Kalirungkut, Surabaya 60293 \\ Email: karinacitrarani@staff.ubaya.ac.id
}




\section{INTRODUCTION}

Hypertension is one of the degenerative diseases suffered by geriatric patients. It is a cardiovascular disease with increased prevalence in older adults (Dipiro et al., 2008). Atenolol is a $\beta$ blocker ( $\beta 1$-selective) antihypertensive drug that is widely used for the treatment of all lines of hypertension, angina pectoris, arrhythmias, and myocardial infarction (Dipiro et al., 2008). It is also an antihypertensive drug listed in the formulary of the Social Security Administering Agency (BPJS Indonesia) of Health. In oral administration, it is absorbed by approximately 50\%, and most of the absorbed doses reach the systemic circulation. The half-life of atenolol is 6-7 hours with $t_{\max }$ between 2-4 hours (Sweetman, 2009). Atenolol is a compound with low water solubility and dissolution but high permeability (Khirwadkar and Dashora, 2013). The low water solubility results in a slow dissolution process that affects the onset of drug action and atenolol bioavailability in the systemic circulation. The conventional administration of atenolol tablets with a glass of water causes discomfort to geriatric patients as they experience physiological changes, such as difficulty in swallowing and chewing, tremor, and risk of choking (Khirwadkar and Dashora, 2013).

The development of atenolol as orodispersible tablets is an approach to reduce the time required for tablet disintegration and minimize the problems in the conventional administration of tablets, especially in geriatric patients. Orodispersible tablet or orally disintegrating tablet (ODT) is a dosage form that quickly dissolves into fine particles when placed in the oral cavity (European Pharmacopoeia Commission, 2005). It can be absorbed in the mouth, pharynx, and esophagus and dissolved and dispersed in saliva in less than three minutes (European Pharmacopoeia Commission, 2005). Furthermore, ODT has several advantages, including fast dissolution process and drug action, minimum first-pass effect, and increased drug bioavailability (Chandrasekhar et al., 2013). It also facilitates patients in taking medicine and, thereby, increases their drug compliance because (1) it is easily swallowed and effective, (2) it has a relatively good flavor, and (3) patients do not need to chew and drink it with water (Kumare et al., 2013). Therefore, this research developed the formulation of atenolol for orodispersible tablets.

An essential component in the formulation of orodispersible tablets as a dosage form is disintegrant. Selecting a suitable disintegrant is, therefore, necessary mainly to create ODT formulas that meet the required physicochemical characteristics. The use and the selection of disintegrants have to be precise in order to obtain the desired dissolution and disintegration rates (Sulaiman, 2007; Camarco et al., 2006). Disintegrant is one of the additional ingredients in drug formulation that serves to break the tablet into smaller particles, enabling fast dissolution process. A group of disintegrant used in low level in the preparation of tablets is termed superdisintegrant. It is considered to be effective as an excipient in ODTs when applied with concentrations between $10 \%$ and $20 \%$ (Hahm and Augsburger, 2008). One type of superdisintegrant that can be used in ODT formulation is croscarmellose sodium. (Hahm and Augsburger, 2008). Croscarmellose sodium facilitates the disintegration process through the mechanism of swelling, recovery of elastic energy, and capillary action (wicking). It is a fiber-like polymer with a rather short size and adequate flow characteristics. Its long fiber-shaped structure can widen the distance between the constitutive particles of the matrix tablet, which accelerates the disintegration process (Hahm and Augsburger, 2008). Accordingly, a thorough study related to the effects of croscarmellose sodium concentration in the ODT formula on the physicochemical characteristics of the produced ODT.

This research formulated orodispersible tablets of atenolol with croscarmellose sodium as superdisintegrant at different concentrations, namely $10 \%$ (formula 1) and $20 \%$ (formula 2). It also used a control formula, i.e., an orodispersible tablet of atenolol prepared without the addition of croscarmellose sodium (0\%). The formulation stage included pre-compression and post-compression evaluations. The results of this stage determined the most favorable formula based on the physical characteristics of ODT and the dissolution of atenolol. The addition of different concentrations of croscarmellose sodium as a disintegrant was analyzed for its impact on the physicochemical characteristics of ODT, i.e., disintegration time, dispersion time, tablet hardness, and atenolol level.

Pharmaciana Vol. 8, No. 1, May 2018, Page. 87-95 
Furthermore, the pharmaceutically qualified formulas with the best physical properties were tested for their dissolution rate according to the standards issued in the Farmakope Indonesia V (Depkes RI, 2014).

\section{MATERIALS AND METHODS \\ Materials}

The materials used in this study included pharmaceutical components, excipients, and reagents. All of the components and excipients were pharmaceutical grade. The components were atenolol, mannitol DC (direct compress), croscarmellose sodium, Avicel PH 102®, magnesium stearate, Aerosil®, aspartame, and talc. The reagents and other chemicals included methanol (Merck), sodium dihydrogen phosphate (Merck), disodium hydrogen phosphate (Merck), sodium acetate (Merck), and glacial acetic acid (Merck). All of the reagents and chemicals were analytical grades.

\section{Preparation of the pressed mass}

The composition of the ingredients used in the pressed mass is presented in Table I. This study used three formulas for the production of orodispersible tablets of atenolol with croscarmellose sodium as superdisintegrant. The formulas included a control $(0 \%)$, formula 1 (10\% of croscarmellose sodium), and formula 2 (20\% of croscarmellose sodium). The pressed mass of each formula was prepared by initially mixing atenolol with some of Aerosil ${ }^{\circledR}$ for 3 minutes and then with some of the Avicel PH 102® for 5 minutes. The next step was the addition of croscarmellose sodium as the superdisintegrant with different concentrations according to the formulas $(0 \%, 10 \%$, or $20 \%)$, aspartame, mint flavor, the rest of the Avicel PH 102®, and mannitol DC. These components were mixed in a tumbling mixer until homogeneous for 10 minutes. This process produced the powder form of the orodispersible tablets before compression.

Table I. The formulas of the orodispersible tablets of atenolol with croscarmellose sodium at concentrations of $0 \%$ (control), $10 \%$ (formula 1), and $20 \%$ (formula 2)

\begin{tabular}{|c|c|c|c|}
\hline Ingredients & $\begin{array}{c}\text { Control } \\
\text { Formula } \\
(\mathbf{m g})\end{array}$ & $\begin{array}{c}\text { Formula } 1 \\
\quad(\mathrm{mg})\end{array}$ & $\begin{array}{c}\text { Formula } 2 \\
\quad(\mathrm{mg})\end{array}$ \\
\hline Atenolol & 25 & 25 & 25 \\
\hline Croscarmellose sodium & - & 30 & 60 \\
\hline Aspartame & 9 & 9 & 9 \\
\hline Mg Stearate & 4.5 & 4.5 & 4.5 \\
\hline Aerosil & 1.5 & 1.5 & 1.5 \\
\hline Talc & 3 & 3 & 3 \\
\hline Mint Flavor & 3 & 3 & 3 \\
\hline Mannitol DC & 50.8 & 44.8 & 38.8 \\
\hline Avicel PH $102^{\circledR}$ & 203.2 & 179.2 & 155.2 \\
\hline Total weight per tablet & 300 & 300 & 300 \\
\hline
\end{tabular}

\section{Pre-compression evaluation}

After the powder form of the orodispersible tablets was created, a pre-compression evaluation was performed. It analyzed the flow rate, angle of repose, compressibility index, Hausner ratio, and moisture content of the powder.

\section{Flow rate and angle of repose}

The flow rate and angle of repose were identified by weighing 100 grams of the powder form. This powder was poured into a funnel set on a stative, and the distance between the lower end of the 
pipe to the flat plane was $10.0 \pm 0.2 \mathrm{~cm}$. The lower hole of the funnel was closed. This hole was then opened later, and the time required for the material to flow out of the funnel was recorded with a stopwatch for flow rate calculation. The next step was measuring the height of the material pile and the radius of the cone base, as well as calculating the resultant angle of repose (Aulton and Summers, 2013).

\section{Compressibility index}

The compressibility index of the powder form was determined by measuring two types of bulk density, namely freely settled bulk density and tapped bulk density of the powder form (Aulton and Summers, 2013). Both data were used to calculate the compressibility index of the powder using the following equation:

$$
\text { Compressibility Index }=\frac{\rho_{T}-\rho_{B}}{\rho_{T}} \times 100 \%
$$

where:

$\rho_{\mathrm{T}}$ : freely settled bulk density of the powder

$\rho_{\mathrm{B}}$ : tapped bulk density of the powder

\section{Hausner ratio}

Hausner ratio compares the tapped bulk density with the freely settled bulk density of the powder (Aulton, 2013). Both Hausner ratio and compressibility index were used to predict the flowability of the powder.

\section{Moisture content}

The moisture content was measured by weighing 5 grams of the powder form. The surface of the powder was flattened on the container. The position of the heating lamp was arranged in a way that it was above the material. During the drying process, the weight of the powder was displayed every 15 minutes.

A drying process is deemed perfect when the weight of the powder does not change for $3 \times 15$ minutes (Aulton \& Summers, 2013). Moisture content was calculated using the following formula:

where:

$$
\% M C=\frac{W-W_{0}}{W_{0}} \times 100 \%
$$

$M C$ : moisture content

$W \quad$ : wet weight of the powder

$W_{0}:$ dry weight of the powder

\section{Compression of orodispersible tablets of atenolol}

Before the compression process from a powder into a tablet dosage form, the powder was mixed first with the external phase, i.e., magnesium stearate, talc, and the remaining Aerosil ${ }^{\circledR}$ using a tumbling mixer for three minutes until homogeneous. This powder mixture was then compacted into a tablet dose using ERWEKA ${ }^{\circledR}$ AR 402 tablet compression machine, and the weight of each tablet was $300 \mathrm{mg}$. The diameter of the punch was $11 \mathrm{~mm}$, the surface of the punch was round and biconvex, and the compression force was 2 tons.

\section{Post-compression evaluation}

After the powder form was pressed into a tablet dose, a post-compression assessment was performed. Aside from organoleptic analysis, the evaluated properties were atenolol content, hardness, disintegration time, tablet dispersion time, friability, and dissolution. 


\section{Organoleptic analysis}

This analysis was conducted by observing the physical appearance of every tablet produced by each formula, including the odor, color, flavor, and shape of the compressed orodispersible tablets of atenolol.

\section{Identification of atenolol content}

The atenolol levels were assessed by sampling 20 tablets of each formula randomly. The twenty samples were crushed together. A mixture of atenolol that was equivalent to $25 \mathrm{mg}$ was weighed and dissolved with $10 \mathrm{~mL}$ of methanol in a measuring flask, then added with acetate buffer solution $(\mathrm{pH}$ 4.6) up to $100 \mathrm{~mL}$. Ten $\mathrm{mL}$ of this solution was transferred with a pipet into a measuring flask and added with acetate buffer solution up to $25 \mathrm{~mL}$. This solution was filtered with Whatman paper No.41. The absorbance of the filtered solution was measured with UV-VIS spectrophotometer at a wavelength of $274 \mathrm{~nm}$ using an acetate buffer blank (pH 4.6) (Chandrasekhar et al., 2013).

\section{Evaluation of tablet hardness}

The tablet hardness was evaluated using the instrument 'Monsanto hardness tester'. The number of samples collected from each formula for this evaluation was ten tablets.

\section{Disintegration time test}

Disintegration time is a critical parameter to observe in the evaluation of orodispersible tablets. The disintegration time was tested by placing 6 tablets (of each formula) into 6 different tubes containing $900 \mathrm{~mL}$ of water with a temperature of $37 \pm 0.5^{\circ} \mathrm{C}$. As the test apparatus started, the stopwatch was turned on. The length of time that the tablet required to disintegrate, or the duration that the core mass needed to become palpable, was determined as the disintegration time of the tablet (Chandrasekhar et al., 2013; Kumare et al., 2013).

\section{In vitro dispersion time test}

Each tablet from the three formulas was placed in a beaker containing $6 \mathrm{~mL}$ of phosphate buffer solution ( $\mathrm{pH}$ 6.8) with a temperature of $37 \pm 0.5^{\circ} \mathrm{C}$. The time required by the tablet to crumble was recorded as the in vitro dispersion time (Chandrasekhar et al., 2013; Kumare et al., 2013).

\section{Friability and abrasion tests}

The friability and abrasion tests were performed by selecting several tablets until a weight of 6.5 gram was reached, i.e., approximately 22 tablets (for tablets weighing lower than $650 \mathrm{mg}$ ). These tablets were weighed using an analytical balance. Afterward, they were placed into the friability and abrasion tests instrument, which was operated at $25 \mathrm{rpm}$ for 4 minutes. The weight of the entire tablets was recorded, and the weight difference between the tablets before and after the test was calculated (Chandrasekhar et al., 2013; Aulton and Summers, 2013). The percentage of friability or abrasion was calculated using the following formula:

$$
\% \text { friability }=\frac{\text { Initial weight }- \text { Final weight }}{\text { Intial weight }} \times 100 \%
$$

\section{Dissolution test}

The dissolution test of the orodispersible tablets of atenolol was performed on a dissolution media, i.e., $900 \mathrm{~mL}$ of $0.1 \mathrm{~N}$ acetic acid buffer $(\mathrm{pH} 4.6)$, according to the standardized procedure issued in Farmakope Indonesia V (Depkes RI, 2014). The dissolution test apparatus used the type 2 (paddle) at $50 \mathrm{rpm}$. The first step was inserting six tablets of each formula into the apparatus. Then, 10 $\mathrm{mL}$ of samples was drawn every time of observation, namely $0,1,2,3,4,5,10,15,20,25,30,45,60$, 
75, 90, 105, and $120 \mathrm{~min}$. Afterward, $10 \mathrm{~mL}$ of $0.1 \mathrm{~N}$ acetic acid (pH 4.)6 was returned to the apparatus. The next step was assessing the atenolol level of each sample using a spectrophotometer at a wavelength of $274 \mathrm{~nm}$. The dissolution parameter (\% Q, tQ\%, the area under the dissolution curve (AUC), and dissolution efficiency) and dissolution profile were identified based on the readings (Chandrasekhar et al., 2013). The dissolution of AUC was determined by calculating the area formed under the dissolution profile. Dissolution efficiency was defined as the area under the dissolution curve until a certain time limit and expressed as a percentage of the rectangle are depicted by $100 \%$ dissolution at the same time limit (Khan, 1975).

\section{Data Analysis}

The post-compression evaluation results of the orodispersible tablets of atenolol created with the control formula ( $0 \%$ of croscarmellose sodium), formula 1 (10\% of croscarmellose sodium), and formula 2 (20\% of croscarmellose sodium) were statistically analyzed using One-way ANOVA with 95\% confidence level $(\alpha=0.05)$. The examined parameters included disintegration time and in vitro dispersion time. The AUC dissolution and dissolution efficiency of the selected formula were compared with the control formula using a pooled t-test.

\section{RESULTS AND DISCUSSION}

The orodispersible tablets of atenolol in this research were prepared using croscarmellose sodium as superdisintegrant. The formula designed in this study aimed to determine the effects of different concentrations of croscarmellose sodium on the physicochemical characteristics of the resulted tablets. A control formula was designed without superdisintegrant. Meanwhile, formula 1 and formula 2 used $10 \%$ and $20 \%$ of croscarmellose sodium, respectively. The pre-compression evaluation was performed on the powder form of these three formulas. It included flow rate, angle of repose, compressibility index, Hausner ratio, and moisture content. The results of the pre-compression evaluation are presented in Table II.

Table II. The results of the pre-compression evaluation of the orodispersible tablets of atenolol with different concentrations of croscarmellose sodium $(0 \%, 10 \%$, and $20 \%)$

\begin{tabular}{lcccc}
\hline \multicolumn{1}{c}{ Parameters } & \multicolumn{3}{c}{ Formulas* } & Standards \\
\cline { 2 - 4 } & $\begin{array}{c}\text { Control } \\
(\mathbf{0 \%})\end{array}$ & $\begin{array}{c}\text { Formula 1 } \\
(\mathbf{1 0 \% )}\end{array}$ & $\begin{array}{c}\text { Formula 2 } \\
\mathbf{( 2 0 \% )}\end{array}$ & \\
\hline Flow rate $(\mathrm{g} / \mathrm{s})$ & $9.31 \pm 0.16$ & $7.10 \pm 0.82$ & $7.38 \pm 0.31$ & $4-10$ \\
Angle of repose $\left({ }^{\circ}\right)$ & $32.15 \pm 0.00$ & $27.84 \pm 01.35$ & $29.53 \pm 0.29$ & $5^{\circ}-35^{\circ}$ \\
Compressibility $(\%)$ & $23.69 \pm 0.499$ & $25.48 \pm 1.07$ & $27.55 \pm 0.36$ & $<25 \%$ \\
Hausner Ratio & $1.32 \pm 0.006$ & $1.34 \pm 0.02$ & $1.38 \pm 0.01$ & $<1.25$ \\
Moisture content $(\%)$ & $4.80 \pm 0.234$ & $5.11 \pm 0.15$ & $5.28 \pm 0.56$ & $3-5 \%$ \\
\hline
\end{tabular}

*The figures represent the average values

The flow rates of the three formulas were between the range of 4-10 g/s, indicating sufficient flow characteristics (Hahm and Augsburger, 2008; Aulton and Summers, 2013). The angle of repose was employed in this study to characterize the flow of a solid particle as it served as an indicator of interparticle friction or movement resistance between particles (United States Pharmacopeia Convention, 2017). Based on the angle of repose, both formula 1 and formula 2 had an excellent flow characteristic, whereas the control formula was categorized as a powder with sufficient flow.

The assessment of compressibility index and Hausner ratio aimed to identify the characteristics of the powder form during tableting. The threshold for good powder compressibility is smaller than $20 \%$ (Agoes, 2012). The Hausner ratio can be divided into three groups, namely excellent flow (1.001.11), good flow (1.12-1.18), and sufficient flow (1.19-1.25). The results of both compressibility index

Pharmaciana Vol. 8, No. 1, May 2018, Page. 87-95 
and Hausner ratio categorized the control formula and formula 1 as a passable powder or, in other words, a powder could flow. On the contrary, formula 2 was concluded as a category of powder with poor flow. Based on the angle of repose, Hausner Ratio, and compressibility index, the powder form had a good flow with some obstacles. The poor Hausner ratio and compressibility index were caused by the presence of a large number of fine particles in the powder (Aulton and Summers, 2013). The moisture contents of control formula, formula 1 , and formula 2 were $4.80 \%, 5.11 \%$, and $5.28 \%$, respectively. The presence of hygroscopic excipient caused such high moisture content. The superdisintegrant used in this research had a high affinity for water so that the powder absorbed moisture from the air (Aulton and Summers, 2013). The moisture content of a powder form has to be controlled to prevent sticking or picking on the punch during the tablet compression process.

The post-compression evaluation in this study included organoleptic examination and tests of atenolol level, tablet hardness, disintegration time, in vitro dispersion time, friability, abrasion, and dissolution. The results are summarized in Table III. The organoleptic characteristics of control formula, formula 1, and formula 2 were round, white, sweet flavor, and minty odor. The physical appearance of the orodispersible tablets of atenolol produced in this study is presented in Figure I.

The atenolol contents in control formula, formula 1, and formula 2 met the thresholds set by the Farmakope Indonesia, namely 90\%-110\% (Depkes RI, 2014). The orodispersible tablets of atenolol must have sufficient physical strength to withstand various mechanical shocks during the manufacturing, packaging, and delivery processes. The orodispersible tablets of atenolol produced in this research had an excellent hardness between the range of 2-4 $\mathrm{kg}$ (Deshmukh et al., 2012; Sharma, 2013). The three formulas met the standards for ODT hardness.

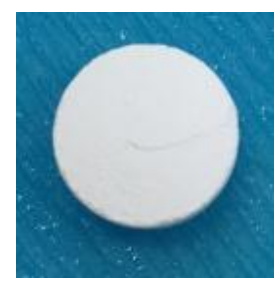

Figure 1. The orodispersible tablet of atenolol with croscarmellose sodium as superdisintegrant

Table III. The results of the post-compression evaluation of the orodispersible tablets of atenolol with different concentrations of croscarmellose sodium $(0 \%, 10 \%$, and 20\%)

\begin{tabular}{lcccc}
\hline \multicolumn{1}{c}{ Parameters } & \multicolumn{3}{c}{ Formulas* } & Standards \\
\cline { 2 - 4 } & $\begin{array}{c}\text { Control } \\
(\mathbf{0 \% )}\end{array}$ & $\begin{array}{c}\text { Formula 1 } \\
\mathbf{( 1 0 \% )}\end{array}$ & $\begin{array}{c}\text { Formula 2 } \\
\mathbf{( 2 0 \% )}\end{array}$ & \\
\hline Organoleptic & $\begin{array}{c}\text { Round, white, } \\
\text { sweet flavor, } \\
\text { minty odor }\end{array}$ & $\begin{array}{c}\text { Round, white, } \\
\text { sweet flavor, } \\
\text { minty odor }\end{array}$ & $\begin{array}{c}\text { Round, white, } \\
\text { sweet flavor, } \\
\text { minty odor }\end{array}$ & $\begin{array}{c}\text { Round, white, } \\
\text { sweet flavor, } \\
\text { minty odor }\end{array}$ \\
Atenolol level (\%) & $93.99 \pm 0.13$ & $109.10 \pm 0.13$ & $108.51 \pm 0.22$ & $90.0-110.0 \%$ \\
Hardness (kP) & $2.85 \pm 0.24$ & $3.15 \pm 0.58$ & $2.90 \pm 0.21$ & $2-4$ Kp \\
Disintegration time & $4.00 \pm 0.00$ & $2.57 \pm 0.00$ & $2.89 \pm 0.00$ & $<3$ minutes \\
(s) & & & & \\
In vitro dispersion & $15.00 \pm 0.00$ & $4.44 \pm 0.41$ & $7.29 \pm 0.56$ & - \\
time & & & & \\
Friability (\%) & $0.20 \pm 0.09$ & $0.07 \pm 0.03$ & $0.17 \pm 0.08$ & $<1 \%$ \\
Abrasion (\%) & $0.25 \pm 0.18$ & $0.07 \pm 0.02$ & $0.07 \pm 0.02$ & $<1 \%$ \\
\hline
\end{tabular}

$*$ The figures represent the average values 
This research also evaluated the disintegration time and the in vitro dispersion time of the produced tablets. Favorable disintegration time for orodispersible tablets of atenolol is less than 3 minutes ( $\leq 180$ seconds) (European Pharmacopoeia Commission, 2005). All of the three formulas met the standards of tablet disintegration time in the purified water. Formula 1, containing $10 \%$ of croscarmellose sodium, had the shortest disintegration time. In vitro dispersion time predicts the ability of an orodispersible tablet to break into fine particles with a very limited volume of saliva $( \pm 6$ $\mathrm{ml}$ ). The statistical analysis, i.e., One-way ANOVA, showed that there was a significant difference of disintegration time between the three formulas $(\mathrm{p}<0.05)$. Furthermore, the results of the post hoc Tukey test showed that the dispersion time of formula 1 (10\% of croscarmellose sodium) was faster than the other formulas. A rapid dispersion time indicates that the tablet is immediately dispersed into fine particles when in contact with saliva in the oral cavity (Nagendrakumar et al., 2010). Based on the evaluation of the physical characteristics, formula 1 (10\% of croscarmellose sodium) produced relatively fast disintegration time compared to control formula and formula 2. Increased concentration of croscarmellose sodium from $10 \%$ to $20 \%$ caused both disintegration time and in vitro dispersion time become longer because this superdisintegrant expanded when in contact with aqueous media. This condition triggers the formation of viscous barrier on the tablet surface, inhibiting the penetration of water into the tablet (Desai et al., 2014).

Based on the physical properties, formula 1 (10\% of croscarmellose sodium) is the best formula regarding pre-compression and post-compression characteristics (disintegration time and in vitro dispersion time). Therefore, the dissolution properties of formula 1 were identified, and the results were compared with the dissolution of the control formula. The dissolution profiles of formula 1 and the control formula are depicted in Figure 2, while the calculation results of the dissolution parameters of both formulas are summarized in Table IV.

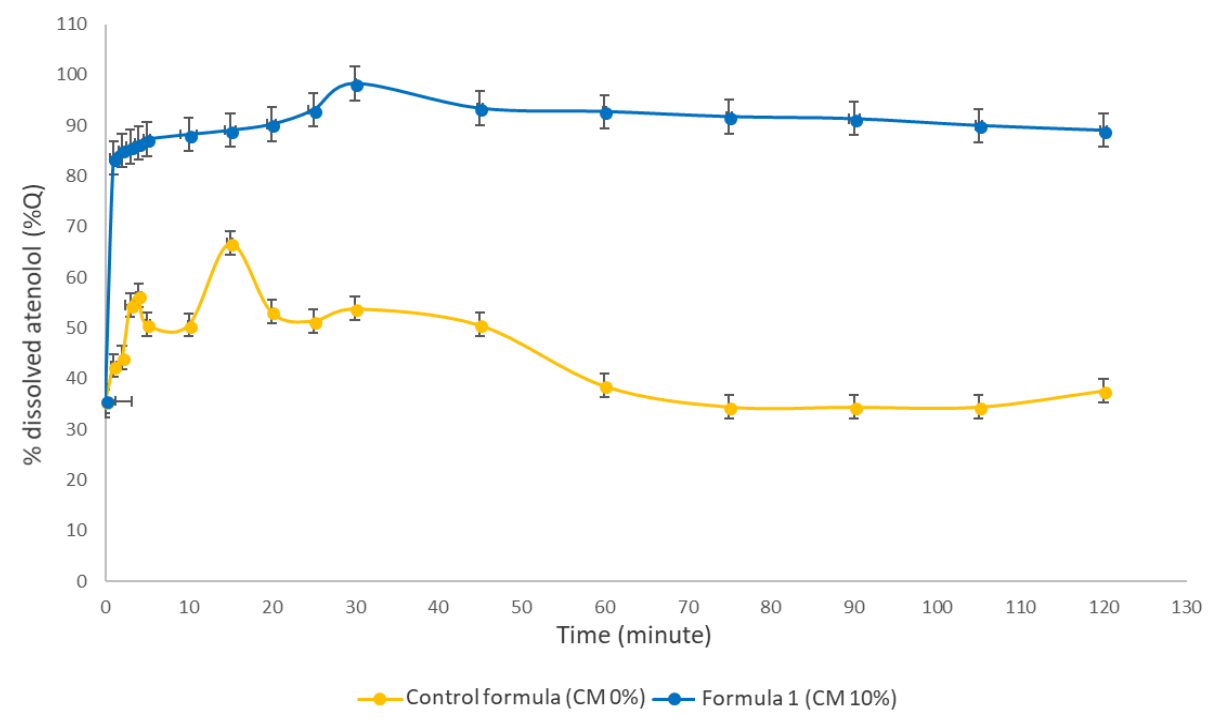

Figure 2. The dissolution profiles of orodispersible tablets of atenolol produced with control formula $(0 \%$ of croscarmellose sodium) and formula $1(10 \%$ of croscarmellose sodium) 
Table IV. The dissolution parameters of the orodispersible tablets of atenolol produced with the control formula and formula 1

\begin{tabular}{|c|c|c|}
\hline Dissolution Parameters & Control Formula & Formula 1 \\
\hline AUC & $5,190.32 \pm 2.78$ & $10,964.99 \pm 27.99$ \\
\hline $\begin{array}{l}\text { Dissolution efficiency } \\
\left(\mathrm{ED}_{120 \text { minutes }}(\%)\right)\end{array}$ & $43.25 \pm 0.02$ & $91.37 \pm 0.23$ \\
\hline$\% \mathrm{Q}(30$ minutes $)$ & 53.85 & $98.31 \%$ \\
\hline tQ\% (minutes) & 270.84 & 1.91 \\
\hline K dissolution & $0.1893 /$ minute & $0.4150 /$ minute \\
\hline
\end{tabular}

Based on the unpaired t-test, the AUC values and dissolution efficiencies of formula 1 and the control formula are different $(\mathrm{p}<0.05)$. The dissolution efficiency of formula $1(10 \%$ of croscarmellose sodium) is twice higher than the control formula. Furthermore, the orodispersible tablets of atenolol prepared using formula 1 met the requirements of ODT dissolution. The amount of dissolved atenolol (formula 1) in 30 minutes was $98.31 \%$, which is higher than the standard set by the Farmakope Indonesia, i.e., 85\% (Depkes RI, 2014).

\section{CONCLUSIONS}

In this study, the different concentrations of croscarmellose sodium as superdisintegrants in the formulation of orodispersible tablets of atenolol affect the physicochemical properties of the ODT. Orodispersible tablets of atenolol prepared with $10 \%$ of croscarmellose sodium (formula 1) exhibit optimum results in both pre-compression and post-compression evaluations. This formula successfully produces ODT of atenolol with the fastest disintegration time and the highest dissolution compared to the other formulas.

\section{ACKNOWLEDGMENTS}

Authors would like to thank the Indonesian Ministry of Research, Technology, and Higher Education and the Institute for Research and Community Service (LPPM) of Surabaya University for their financial support during this research under the scheme of Research of Applied Product 2017. Authors would also like to express their gratitude to the research team of orodispersible tablets of atenolol (Meilany and Stephanie).

\section{REFERENCES}

Agoes, G., 2012. Sediaan Farmasi Padat $1^{\text {st }}$ edition. Bandung, Penerbit ITB., 135-153.

Aulton, M., and Summers M., 2013. Tablet and Compaction. In: Pharmaceutics the Science of Dosage Form Design, $4^{\text {th }}$, Philadelphia, Churchill Livingstone, 397-439.

Camarco, W., \& Druffner, A., 2006. Selecting superdisintegrant for orally disintegrating tablet formulation, Pharmaceutical Technology, 5, 1-5.

Chandrasekhar, P., Shahid, M.S., and Niranjan, B.M., 2013. Formulation and Evaluation of Oral Dispersible Tablets of Anti Hypertensive Drug Atenolol. International Journal of Pharmacy, 3 (2), 79-84.

Departemen Kesehatan Republik Indonesia (Depkes RI), 2014. Farmakope Indonesia Edisi V, Departemen Kesehatan Republik Indonesia, Jakarta.

Desai, P.M., Hua, P.X., Liew, C.V., and Heng, P.W., 2014. Functionality of Disintegrants and Their Mixtures in Enabling Fast Disintegration of Tablets by a Quality by Design Approach. American Association of Pharmaceutical Scientists, 15(5): 1093-1104.

Desmukh, D.P., Ghotaskar, A., and Burande, M., 2012. A Review on Fast Dissolving Tablet. Pharma Science Monitor, 3 (4): 3360-75. 
Dipiro, J.T., Talbert, R.L., Yee, G.C., Matzke, G.R., Wells, B.G., and Posey, L.M., 2008. Pharmacotherapy: A Pathophysiologic Approach Seventh Edition, New York, McGraw-Hill, 139-140.

Hahm, H.A., and Augsburger, L.L., 2008. Orally disintegrating tablets and related tablet formulations. In Pharmaceutical Dosage Forms: Tablets, New York, Informa Healthcare, 293-312.

Khirwadkar, P., and Dashora, K., 2013, Formulation and evaluation of fast dissolving tablets Atenolol. Journal of Chemical and Pharmaceutical Research, 6 (2), 113-19.

European Pharmacopoeia Commission, 2005. European Pharmacopoeia $5^{\text {th }}$ edition, Council of Europe, Uppsala.

Kumare, M.M., Marathe, R.P., Kawade, R.M., Ghante, M.H., and Shendarkar, G.R., 2013. Design of fast dissolving tablet of Atenolol using novel co-processed superdisintegrant. Asian Journal of Pharmaceutical and Clinical Research, 6(3): 81-85.

Nagendrakumar, D., Raju, S.A., Shirshand, S.B., and Para, M.S., 2010. Design of Fast Dissolving Granisetron HCL Tablets Using Novel Co-Processed Superdisintegrants. International Journal of Pharmaceutical Science Review and Research, 1(1): 58-62.

Sharma, D., 2013. Formulation Development and Evaluation of Fast Disintegrating Tablets of Salbutamol Sulphate for Respiratory Disorders. International Scholarly Research Notices Pharmaceutics, 1-8.

Sulaiman, T.N.S., 2007. Teknologi dan Formulasi Sediaan Tablet, Pustaka Laboratorium Teknologi Farmasi Fakultas Farmasi Universitas Gadjah Mada, Yogyakarta, 80-110,128,150-159,200.

Sweetman, S.C., 2009, Martindale The Complete Drug Reference Thirty-Six Edition, Chicago, Pharmaceutical Press, 1217-18.

United States Pharmacopeia Convention, 2017. United States Pharmacopeia 40 National Formulary 35, Rockville, United States Pharmacopeia Committee. 